International Session 2

\title{
Cigarette Smoke-induced Cell Death Causes Persistent Olfactory Dysfunction in Aged Mice
}

\author{
タバコ煙による細胞死誘導により, \\ 加齢マウスでの嗅覚障害が持続する
}

\author{
Rumi Ueha, Kenji Kondo, Shu Kikuta, Tatsuya Yamasoba \\ Department of Otolaryngology, The University of Tokyo, Tokyo, Japan
}

上羽 瑠美, 近藤 健二, 菊田 周, 山岨 達也

東京大学 耳鼻咽堠科·頭頸部外科

1. はじめに

喫煙による嗅覚障害のメカニズムとし，我々はこれま でにタバコ煙溶液 (cigarette smoke solution: CSS) 投与 により嗅上皮のSOX2 $2^{+}$嗅覚前駆細胞を障害し, $\mathrm{OMP}^{+}$ 成熟嗅神経細胞 (ORNs) の低下と嗅覚障害が生じるこ とを示し, 炎症性サイトカインのIL-1 $1 \beta$ IL-6が関与して いることを明らかにしだ（図1)。さらに，MET（メチ マゾール）による嗅上皮障害モデルを用いて, CSS投与 により嗅上皮再生が遅延すること, そしてその機序とし て, 嗅覚前駆細胞の分裂・分化過程を障害することによ る成熟ORNsへの分化抑制とInsulin-like growth factor-1 （IGF-1）の低下を明らかにしてきた ${ }^{2)}$ (図2)。

本研究では, 加齢嗅神経上皮における夕バコ煙の影響 を検証することを目的とし，高炎症状態である「加齢」
マウス ${ }^{3)}$ を用いて, 嗅細胞系への加齢による影響を組織 学的解析および遺伝子解析を行うことで, 嗅覚障害の背 景に迫った。さらに加齢と喫煙に伴う嗅覚障害の背景に ある分子機構を検証した ${ }^{4)} 。$

\section{2. 方法}

C57BL/6 マウス（60週齡）にCSSを点鼻吸入させ, 喫 煙モデルを作製した。対照群には生食を点鼻投与した。 CSS最終投与日をDay 0 とし，Day 1，7，14，28に成熟 ORNs, 嗅覚前駆細胞, 未熟ORNs, 分裂細胞, アポトー シス細胞の細胞数と, 抽出した鼻粘膜mRNA中の炎症性 サイトカイン（Il1b, Tnf, I16）を対照群と定量比較し た。さらに, Day 7, 14, 28に嗅覚行動実験にて匂い物 質への反応時間を計測した。

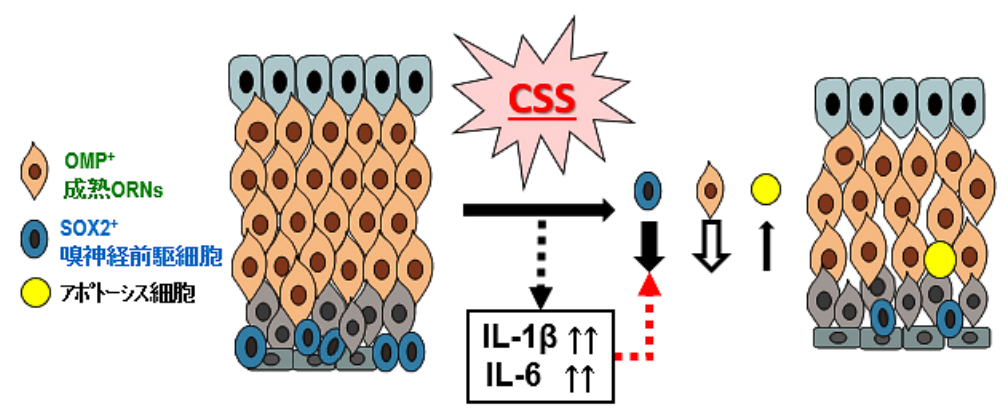

図1 CSSによる嗅神経上皮障害の機序 


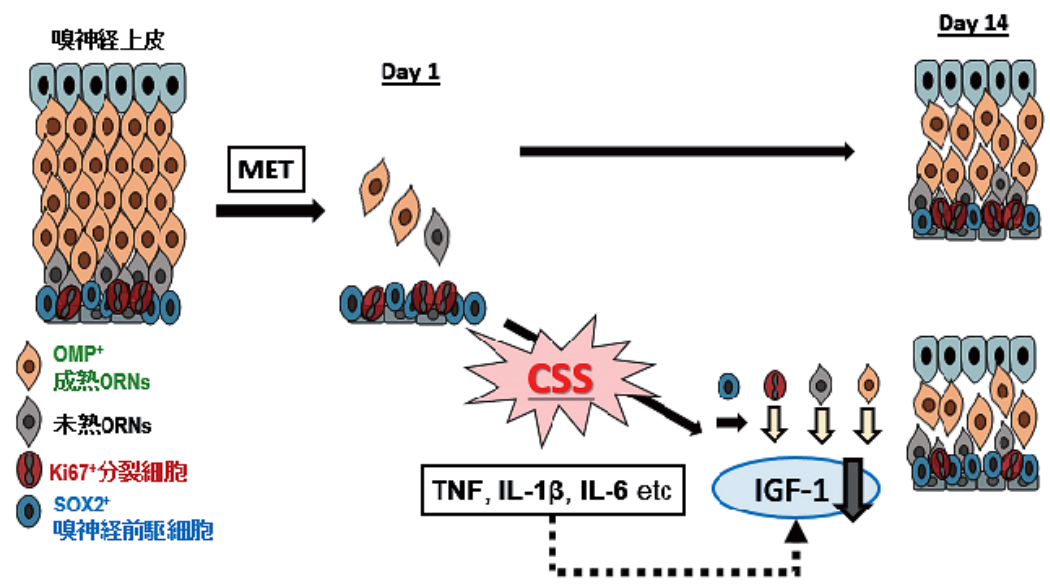

図2 MET障害モデルを用いたCSSによる嗅神経上皮障害再生後遅延の機序

A

Saline-treated

Day 1

Day 7

Day 14

Day 28

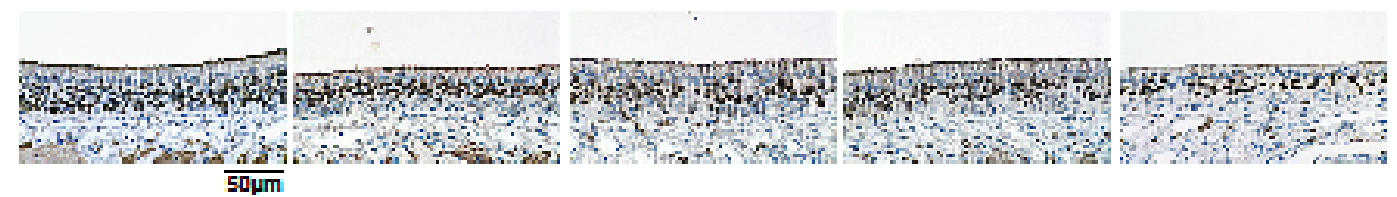

B

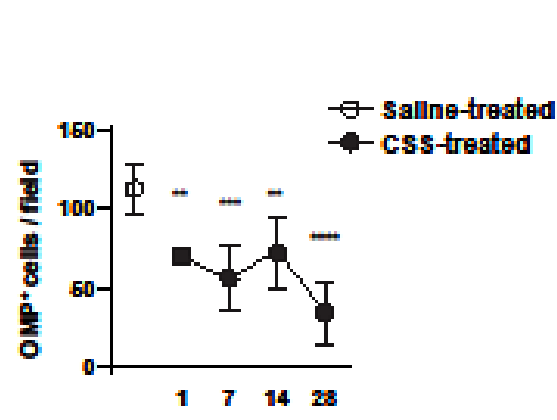

Days post final CSS dose
C

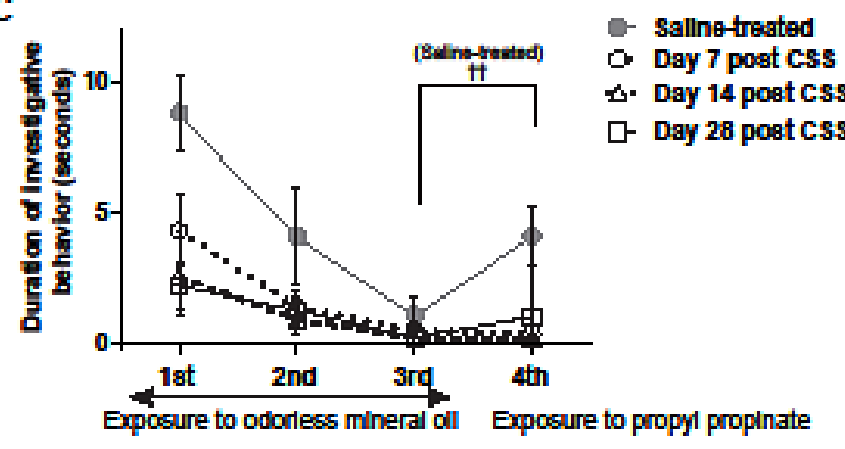

図3 A， B. 加齢マウスにおけるCSS投与後の成熟ONRs数の推移，C. 匂い刺激に対する反応

\section{3. 結果}

(1) 加齢モデルではCSS投与により成熟ORNs数が減少 し，投与中止後も減少傾向が続く

$\mathrm{OMP}^{+}$成熟嗅細胞数は, 対照群と比較してDay 1 で有意 に低下し, その後もDay 28 までに緩徐に減少した（図 3-A, B)。

(2) 加齢群ではCSS投与による嗅覚障害が投与終了後も 持続する

CSS最終投与後Day 1，7，14，28に施行した行動実験 では, どのポイントでも匂い刺激に反応しなかった(図 $3-\mathrm{C})$ 。

(3) CSS最終投与後のアポトーシス亩進が加齢モデル
CSS投与後嗅神経上皮再生を障害する

CSS最終投与後 1 日目に基底層の細胞分裂 $\left(\mathrm{Ki} 67^{+}\right)$が 増加したが，7日目にはSOX2+嗅覚前駆細胞，Ki67+ 分裂細胞, Cas3 3 アポトーシス細胞がともに増加した。 14 日目ではSOX2 $2^{+}$嗅覚前駆細胞, Ki67 ${ }^{+}$分裂細胞は対 照群と差がなくなったが, アポトーシス細胞は増加傾 向が続いていた。CSS投与後のアポトーシス増加が成 熟ORNs数の減少に関与すると考えられた。

(4) 高炎症状態の加齢モデルにおいて炎症性サイトカイ ンの増加は限定的である

TnfはCSS投与後Day 1，7で有意に上昇した一方で, $I l 1 b$ はもともとの高炎症状態を維持し，Il6はCSS投与 後からDay 28 まで有意に低下していた（図4）。 
II1b

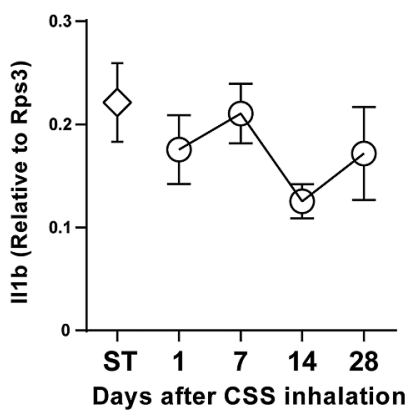

Tnf

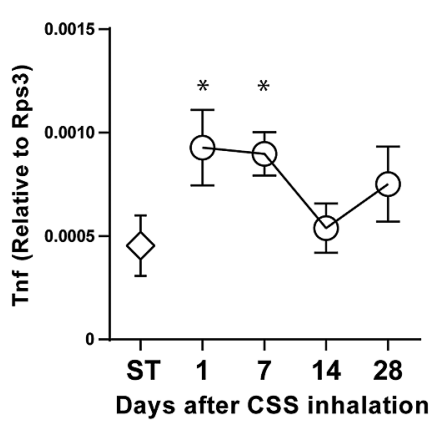

II6

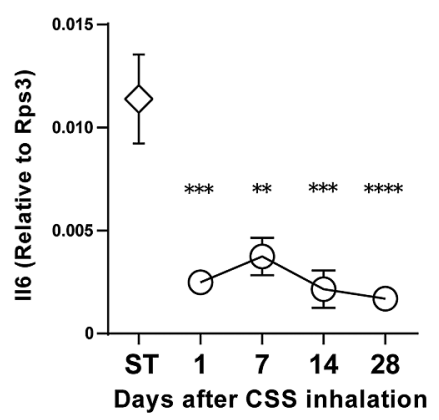

図4＼cjkstart鼻粘膜中の炎症性サイトカインの推移

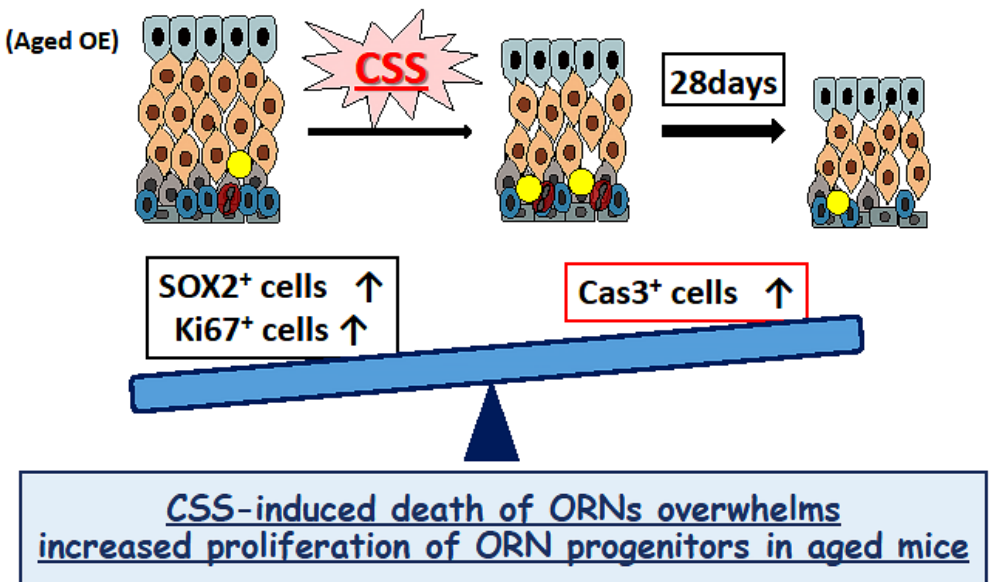

図5 加齢マウスにおけるCSS投与後のONRs数バランス

\section{4. 考察・まとめ}

本研究で, 夕バコ煙曝露は加齢マウスの嗅神経細胞の 細胞死を立進させることで嗅神経細胞数が減少させ，嗅 覚障害遷延化に繋がることを示した。つまり，夕バコ煙 長期間暴露による細胞死の立進は, 嗅神経細胞の高い再 生能を凌駕することを示唆しており（図5），その効果は 夕バコ煙曝露後28日でも持続することが判明した。細胞 死の誘導には炎症性サイトカインが一役を担っていると され，本研究でもCSS投与後のTnfの上昇を認めた。Tnf は嗅神経前駆細胞や嗅神経上皮の恒常的な再生を抑制す ることから, CSS投与後の嗅神経上皮再生遅延も説明可 能である。しかしながら，I16はCSS投与後から著明に発 現低下していた。I16に関してはアポトーシスを抑制して 細胞増加を誘導し組織保護的機能を有するという説から, 障害後の組織再生を抑制するという説など，様々な役割 を担っていると想定されることを考慮すると，CSS投与 後嗅神経上皮においては, 組織保護的な役割を有する可 能性が考えられた。
本研究では, タバコ煙誘導性の嗅覚障害に関する機序 の一部を解明し, Tnf抑制や細胞死の抑制が治療のター ゲットである可能性を明らかにした。嗅覚刺激は嗅神経 上皮から嗅球，大脳皮質へ投射されることから，CSSに よる嗅覚への影響に関して，嗅神経上皮のみならず嗅覚 中枢への影響に関する検証も必要である。

本稿はFrontia in Aging Neuroscience (https://doi. org/10.3389/fnagi.2018.00183）に掲載されている内容を 要約して記載した。

\section{参考文献}

1) Ueha R, Ueha S, Kondo K, et al : Damage to olfactory progenitor cells is involved in cigarette smokeinduced olfactory dysfunction in mice. Am J Pathol 2016 ; 186 : 579-586.

2) Ueha R, Ueha S, Sakamoto T, et al : Cigarette smoke delays regeneration of the olfactory epithelium in mice. Neurotox Res 2016 ; 30 : 213-224. 
3) Ueha R, Shichino S, Ueha S, et al : Reduction of proliferating olfactory cells and low expression of extracellular matrix genes are hallmarks of the aged olfactory mucosa. Front Aging Neurosci 2018. https://doi.org/10.3389/fnagi.2018.00086.
4) Ueha R, Ueha S, Kondo K, et al : Cigarette smokeinduced cell death causes persistent olfactory dysfunction in aged mice. Front Aging Neurosci 2018 https://doi.org/10.3389/fnagi.2018.00183. 